Перспективи подальших розвідок. Виконане дослідження не вичерпує усіх аспектів окресленої проблеми. До перспективи подальших розвідок відносимо вивчення дидактичної системи, що застосовувалася в означений період, а також аналіз політики уряду Канади щодо розвитку освіти корінних народів в наступні століття.

\section{ЛІТЕРАТУРА}

1. Davinm, N. (1879). Report on the Industrial Schools for Indians and Half-Breeds. Retrieved from: https://archive.org/details/cihm_03651 [in English].

2. Haig-Brown, C. (1998). Resistance and Renewal: Surviving the Indian Residential School. Arsenal Pulp Press, 172 p. [in English].

3. Hare, J. \& Barman, J. (2000). Aboriginal Education: Is There a Way Ahead? In D. Long, P. Dickason (eds.).
Visions of the Heart: Canadian Aboriginal Issues. Toronto: Hardcourt Canada, pp. 331-359. [in English].

4. Hawthorn, H. (1967). A Survey of the Contemporary Indians of Canada. Ottawa: Indian Affairs Branch. vol. 2, 251 p. [in English].

5. Kirkness, V. (2013). Aboriginal Education in Canada: a Retrosprctive and a Prospective. In F. Widdowson, A. Howard (eds.). Approaches to Aboriginal Education in Canada. Brush Education, pp. 7-26. [in English].

6. Milloy, J. (1999). A National Crime: The Canadian Government and the Residential School System 1789 to 1986. University of Manitoba Press, 402 p. [in English].

7. White, J. \& Peters, J. (2013). A Short History of Aboriginal Education in Canada. Aboriginal Education: Current Crisis and Future Alternatives. Thompson Educational Publishing, 2013, pp. 13-31. [in English].

Стаття надійшла до редакції 27.02.2018

УДК 378.147.091.33-027.22:378.22

DOI:

Сергій Ящук, доктор педагогічних наук, професор, доцент кафедри техніко-технологічних дисциплін, охорони праці та безпеки життєдіяльності

Уманського державного педагогічного університету імені Павла Тичини

\title{
КОНЦЕПТУАЛЬНІ ОСНОВИ ПРОФЕСІЙНОЇ ПІДГОТОВКИ МАЙБУТНІХ ВИКЛАДАЧІВ ЗАГАЛЬНОТЕХНІЧНИХ ДИСЦИПЛІН ТА МЕТОДИКИ НАВЧАННЯ ТЕХНОЛОГЙ
}

У статті обтрунтовуються концептуальні основи професійної підготовки майбутніх магістрів технологічної освіти у вищих педагогічних навчальних закладах України. Розкрито теоретичні підходи до розробки конщепџї професійної підготовки магістра технологічної освіти, які відображають науково обтрунтовану побудову структуру змісту техніко-технологічної та методичної системи; визначено основні напрями ї̈ вдосконалення 6 контексті забезпечення якісної традищійної підготовки майбутнього фахівия для вищої педагогічної иколи.

Ключові слова: концепчія; професійна підготовка; технологічна освіта; магістр; викладач.

Jim. 5.

Serhiy Yashchuk, Doctor of Sciences (Pedagogy), Professor, Associate Professor of the TechnoTechnological Disciplines, Labor Protection and Safety of Life Department Uman Pavlo Tychyna State Pedagogical University

\section{THE CONCEPTUALFOUNDATIONSOF PROFESSIONALTRAINING OF MASTERS OFTHETECHNOLOGICAL EDUCATIONINTHE HIGHER PEDAGOGICALEDUCATIONALINSTITUTIONSOFUKRAINE}

The conceptual foundations of educational training of future Masters of technology in the Ukrainian higher educational establishments have been grounded in the article. The basic components of the training, the concepts: a future teacher of general technical subjects, and methods of teaching of technology have been analyzed, they are as follows: training content should be considered from the standpoint of competency approach; training should be based as an integrative unity of educational programs and individual characteristics, the professional interests and intentions of students; the educational process of Masters will take a high quality if during the selection of training content to adhere to the certain principles and systems to create the necessary conditions for the implementation of this content; the qualitative training of future Masters is not possible without an optimal combination of theory and practice.

The theoretical approaches to the development of the concept of Master of technological education training that reflect the scientifically based content structuring of technical and technological and methodological system, the main directions of its improvement in the context of traditional training of future specialist for a higher pedagogical school have been determined.

Keywords: a concept; training; technology education; a Master; a teacher.

П остановка проблеми. Зміни освітньої парадигми в Україні спрямовані на модернізацію вищої школи та підготовку майбутніх фахівців високої кваліфікації, які можуть конкурувати на ринку праці. Сучасна державна політика у сфері освіти
(C) С. Ящук, 2018 


\section{КОНЦЕПТУАЛЬНІ ОСНОВИ ПРОФЕСІЙНОЇ ПІДГОТОВКИ МАЙБУТНІХ ВИКЛАДАЧІВ}

ЗАГАЛЬНОТЕХНІЧНИХ ДИСЦИПЛІН ТА МЕТОДИКИ НАВЧАННЯ ТЕХНОЛОГІЙ

спрямована на пошук нових підходів до організації навчального процесу, модернізацію ідеологічної, філософської та педагогічної парадигми. Соціально-економічні зміни на ринку праці, підвищення суспільних вимог до рівня професіоналізму та конкурентоспроможності майбутніх фахівців спонукають до розв'язання актуальних проблем сучасної системи вищої освіти, пов'язаних із формуванням особистості, іiі діяльності в умовах ринкової економіки. У зв'язку $з$ цим пошук нових підходів до модернізації традиційної підготовки педагогічних кадрів в умовах сучасного освітнього простору стає актуальним і перспективним завданням.

В основу забезпечення якості підготовки фахівців у вищому навчальному закладі покладено: створення умов для подальшого розвитку вищої школи; ефективне використання кадрових і матеріальних ресурсів; мотивація учасників освітнього процесу на постійне вдосконалення своєї діяльності; відвертість системи оцінки якості роботи викладачів, співробітників і студентів.

Аналіз основних досліджень та публікацій. У педагогічній науці актуальними проблемами завжди були і є підвищення якості та ефективності вищої освіти. Адже, проблеми, що стосуються організації та удосконалення навчального процесу вирішували О. Абдулліна, С. Білоконний, Ю. Дацько, Н. Загрязкіна, С. Кара, В. Ковальчук, М. Козій, Н. Казанішена, Л. Кулікова, Л. Манчуленко, В. Олійник, А. Сбруєва, В. Сластьонін, Т. Стрітьєвич, І. Чорней; проблеми професійної підготовки студентів магістратури досліджували Н. Гайдук, Н. Дудник, С. Дворецький, Л. Клос, Л. Козак, І. Козубовська, Ю. Красильник, І. Мигович, Ш. Рамон, С. Саррі, Т. Філат, К. Ханвей, Є. Швець; проблеми підготовки та професійного становлення з позиції компетентнісного підходу майбутніх фахівців технологічної освіти присвячено праці В. Гетти, О. Коберника, М. Корця, В. Кузьменка, Є. Кулика, В. Мадзігона, О. Торубари, А. Цини. Дослідження змісту освіти, визначення принципів побудови його структури передбачає розробку концепції професійної підготовки. В останні роки активізувалися дослідження вітчизняних вчених, щодо розробки концептуальних основ побудови змісту професійної освіти (С. Гончаренко [1], О. Джеджула [2], О. Коберник [3] та ін.).

Метою статті $\epsilon$ обгрунтування концептуальних основ професійної підготовки майбутніх магістрів технологічної освіти у педагогічних закладах вищої освіти.

Виклад основного матеріалу. Одним 3 ключових феноменів педагогічної теорії і практики підготовки фахівця вищої школи, зокрема магістра технологічної освіти, що побудована на інноваційних підходах, є концепція. Концепції $\epsilon$ орієнтиром під час розробки стратегії певної діяльності. В нашому дослідженні концепція спрямована на визначення якісних теоретичних та методичних основ професійної підготовки магістрів технологічної освіти.

Розроблення концепції, як зазначає О. Коберник, передбачає початковий задум зміни педагогічної дійсності, включаючи систему уявлень про те, які повинні відбуватися зміни. Автори концепцій ніби моделюють ідеальний (бажаний) образ освітнього простору, системи (еталон), потім проводять діагностику педагогічних реалій і створюють його реальний образ ..., після чого конструюють механізми переходу освітньої системи в новий якісний стан, моделюють інноваційні процеси [3].

Таким чином, концепція передбачає розкриття суті, функцій професійної підготовки магістрів технологічної освіти, процесу досягнення поставленої мети, тобто умов професійної підготовки магістрів відповідно до вибраних форм, методів і засобів педагогічної діяльності. Концепція має відігравати роль деякої теоретичної побудови, що об'єднує в логічній послідовності сукупність тверджень про загальні закономірності та взаємодію окремих елементів процесу професійної підготовки магістрів технологічної освіти, а також описувати процес професійної підготовки, засоби і методи його реалізації, тобто те, що відображає теорія.

Концептуальні основи дослідження процесу підготовки магістрів технологічної освіти, на нашу думку, мають формуватися виходячи з його ціннісного цільового призначення - визначення змін, які можуть бути здійснені у вищій педагогічній та технологічній освіті з метою підготовки викладачів до вирішення стратегічних завдань модернізації вищої освіти у сфері технологічної підготовки магістрів.

При визначенні цілей і завдань професійної підготовки магістрів технологічної освіти необхідне застосування прогностичного підходу, що дозволить 3 деяким попередженням врахувати тенденції у середній та вищій освіті для внесення необхідних коректив.

До теперішнього часу, щодо визначення цілей професійної підготовки магістрів технологічної освіти, єдиної думки серед педагогів немає. Це пояснюється тим, що визначеності в цілепокладанні не було, а в даний час такі дослідження тільки починаються і не піддаються ще широкому обговоренню. 


\section{КОНЦЕПТУАЛЬНІ ОСНОВИ ПРОФЕСІЙНОЇ ПІДГОТОВКИ МАЙБУТНІХ ВИКЛАДАЧІВ ЗАГАЛЬНОТЕХНІЧНИХ ДИСЦИПЛІН ТА МЕТОДИКИ НАВЧАННЯ ТЕХНОЛОГІЙ}

Мета магістратури з галузі знань "Освіта" зі спеціальності 01410 Середня освіта. Трудове навчання та технології- формування професійнопедагогічної компетентності викладача загальнотехнічних дисциплін та методики навчання технологій в процесі навчальновиховної діяльності у ЗВО на основі використання сучасних досягнень у техніко-технологічній, психолого-педагогічній та методичній сферах.

Основними завданнями магістратури щодо формування професійно-педагогічної компетентності майбугнього магістра є:

- урахування вітчизняного та зарубіжного перспективного педагогічного досвіду реформування освіти та підготовки магістрів в контексті сучасності;

- формування в магістрів навичок науководослідницької роботи шляхом участі в розроблені наукових проектів, тем кафедр, науковопрактичних конференціях, семінарах; підготовці до друку та видання публікацій у наукових збірниках, фахових виданнях; написання та захист наукового дослідження на здобуття ОКР “магістр” тощо.

- використання сучасних технологій та методів навчання і виховання при вивченні дисциплін психолого-педагогічного та загальнотехнічного спрямування;

- набуття навичок педагогічного проектування змісту підготовки вчителя технологій;

- дотримання законодавчих, нормативних документів у галузі освіти.

Об'єктом діяльності магістратури є система психолого-педагогічної, науково-дослідної та техніко-технологічної підготовки викладача загальнотехнічних дисциплін та методики навчання технологій.

Предметом діяльності магістратури зі спеціальності 01410 Середня освіта. Трудове навчання та технології $є$ зміст, форми, методи та технології навчання магістрів 3 техніки та технологій дисциплінам циклів: гуманітарної та соціально-економічної, природничо-математичної та професійно-орієнтованої (професійної та практичної) підготовки.

На нашу думку, якісна професійна підготовка магістра технологічної освіти забезпечуватиметься такими концептуальними положеннями:

1. Зміст професійної підготовки магістрів технологічної освіти необхідно розглядати 3 позицій компетентністного підходу, що відображає не тільки знання, але й сукупність професійно значущих якостей і досвіду, що забезпечують кар'єрне зростання та професійну мобільність. Формування професійних компетентностей майбутнього викладача загальнотехнічних дисциплін та методики навчання технологій здійснювати в процесі реалізації особистісно орієнтованої професійнопедагогічної освіти, що включає проходження магістром основних етапів професійного становлення та забезпечення у професійній самоосвіті.

2. Професійна підготовка майбутнього викладача загальнотехнічних дисциплін та методики навчання технологій повинна будуватися як інтеграційна єдність освітніх програм, 3 одного боку, і індивідуальних особливостей, професійних інтересів і намірів студентів, з іншого, що дозволяє забезпечити самостійний рух майбутніх викладачів від знання основ техніки та технологій до формування загальнотехнічної та методичної системи.

Професійно-педагогічну компетентність розглядати як інтеграційну єдність трьох підструктур: ключову, загальнопредметну та спеціально-предметну компетентність. При цьому ключові та загальнопредметні компетентності відображають культуру професійної діяльності і підрозділяються на: мотиваційну, таку, що відображає особистісну зацікавленість в самостійній професійній підготовці; когнітивну, що характеризує здібності до підвищення своєї професійної майстерності; інформаційну, таку, що відображає наявність умінь і навиків отримання, обробки і застосування інформації в процесі професійної підготовки; комунікативну, що характеризує уміння проектувати і встановлювати педагогічно доцільні взаємини; соціальну, що характеризує усвідомлення соціальної значущості власного професійного розвитку [4].

Спеціально-предметна компетентність інтегрує в собі знання предметів загальнотехнічного спрямування і методики навчання технології та підрозділяється на: иільову (уміння педагога визначати цілі навчання техніки та технології); змістову (уміння визначати зміст навчання техніки та технології); проектувальну (уміння проектувати освітній процес); рефлексію (уміння обгрунтовувати ефективність вибраних методичних підходів); моніторингову (уміння відстежувати результати навчання).

3. Професійнупідготовкумагістрів технологічної освіти доцільно розглядати в аспекті нерозривної єдності техніко-технологічних і психологопедагогічних знань. Виходячи з того, що для професійної підготовки викладача загальнотехнічних дисциплін та методики навчання технології характерні тісний функціональний взаємозв' язок iз техніко-технологічними знаннями й уміннями, 


\section{КОНЦЕПТУАЛЬНІ ОСНОВИ ПРОФЕСІЙНОЇ ПІДГОТОВКИ МАЙБУТНІХ ВИКЛАДАЧІВ ЗАГАЛЬНОТЕХНІЧНИХ ДИСЦИПЛІН ТА МЕТОДИКИ НАВЧАННЯ ТЕХНОЛОГІЙ}

ми вважаємо за доцільне формування професійнопедагогічної компетентності здійснювати в системі техніко-технологічної та методичної підготовки.

Створення системи техніко-технологічної та методичної підготовки магістрів дозволить поглибити наочні знання і уміння, попередити вузьке розуміння педагогом своєї спеціальності, підготувати викладачів 3 широким загальнотехнічним кругозором, які зможуть вільно орієнтуватися в сукупності виробничих і педагогічних процесів.

4. Для забезпечення можливості якісного управління процесом формування професійнопедагогічної компетентності магістра технологічної освіти необхідно побудувати модель професійної підготовки викладача загальнотехнічних дисциплін та методики навчання технології.

Модель професійної підготовки магістра технологічної освіти доцільно створювати відповідно до технології педагогічного проектування на основі виділення структурних блоків системи цієї підготовки: проектнометодологічного, цільового, умовного, особистісного, інфраструктурно-змістового, технологічно-процесуального та моніторингового.

Запропонована модель дасть необхідні уявлення про стратегію формування професійнопедагогічної компетентності в процесі професійної підготовки магістра.

5. Модель формування професійно-педагогічної компетентності майбутнього магістра технологічної освіти реалізується, якщо:

- системотворним елементом професійної підготовки викладача загальнотехнічних дисциплін та методики навчання технології $€$ діалектична єдність професійних намірів студентів і цілей професійно-педагогічної освіти;

- зміст професійної підготовки майбутнього магістра технологічної освіти слід розглядати 3 позиції формування не тільки технікотехнологічних і методичних знань та вмінь, але i мотивацію до педагогічної діяльності, розвиток інформаційної культури, розширення соціокультурного кругозору, накопичення досвіду педагогічної комунікації, формування готовності до педагогічної творчості;

- результатом функціонування моделі формування професійно-педагогічної компетентності магістра технологічної освіти є не тільки формування професійних знань та вмінь, але й розвиток творчої індивідуальності та готовності до самоудосконалення [5].

6. Найважливішою концептуальною ідеєю дослідження $\epsilon$ положення про те, що в процесі підготовки викладача в системі вищої професійної освіти, техніко-технологічна підготовка виконує освітню, виховну, розвиваючу, координуючу та інтегруючу функції, яка реалізовуються в єдності та взаємозв'язку.

Реалізація освітньої функції забезпечує оволодіння студентами системи технологічних та загальнотехнічних знань (понять, законів, принципів, закономірностей виробничого процесу, технологічних операцій).

Виховна функція реалізується в тісному взаємозв'язку процесу засвоєння основ техніки та технології 3 оволодінням технікотехнологічними цінностями й гуманними стосунками, 3 формуванням професійнопедагогічної компетентності майбутнього викладача.

Розвиваюча функція професійної підготовки майбутнього магістра технологічної освіти впливає на розвиток особистості магістранта, на формування його професійних здібностей, творчого відношення до майбутньої професійнопедагогічної діяльності.

Координуюча функція полягає в здійсненні взаємозв'язків дисциплін загальногуманітарного, соціально економічного i професійноорієнтованого циклів через переосмислення, відбір та інтерпретацію техніко-технологічного матеріалу цих дисциплін для застосування в професійно-педагогічній діяльності.

Сенс інтегруючої функції полягає в тому, що професійна підготовка викладача загальнотехнічних дисциплін та методики навчання технологій акумулює знання й уміння, отримані студентами в період базового навчання, і направляє їх на вирішення професійних завдань, що стоять перед майбутнім магістром технологічної освіти.

7. Навчально-виховний процес в магістратурі набуде високої якості, якщо при відборі змісту підготовки викладача загальнотехнічних дисциплін та методики навчання технологій дотримуватися певної системи принципів створити необхідні організаційно-педагогічні та психолого-педагогічні умови для реалізації цього змісту.

8. Якісна підготовка майбутнього магістра не можлива без оптимального поєднання теорії та практики. Технологія встановлення оптимального співвідношення теорії з практикою має кілька аспектів. 3 одного боку, вона передбачає встановлення певного співвідношення між теоретичним і емпіричним типом мислення. 3 іншого боку, в системі знань, які формуються в процесі професійної підготовки фахівця технологічної освіти, об'єктивна частка 


\section{КОНЦЕПТУАЛЬНІ ОСНОВИ ПРОФЕСІЙНОЇ ПІДГОТОВКИ МАЙБУТНІХ ВИКЛАДАЧІВ ЗАГАЛЬНОТЕХНІЧНИХ ДИСЦИПЛІН ТА МЕТОДИКИ НАВЧАННЯ ТЕХНОЛОГІЙ}

емпіричного знання становить досить вагому частку.

Таким чином, важливим аспектом професійної підготовки майбутнього магістра технологічної освіти є оптимальне співвідношення теорії 3 практикою, що забезпечує формування інтегративного знання.

9. Підсумкова державна атестація майбутнього магістра технологічної освіти має передбачати захист магістерської роботи за основним фахом і державні іспити як за основною, так і з додаткової спеціальності (спеціалізації).

За результатами дослідно-експериментальної роботи, аналізу навчальних планів підготовки магістра технологічної освіти провідних вищих навчальних закладів України встановлено, що магістерська робота заміняє один або два державних іспити. Розробники навчальних планів стверджують, що магістерська робота дозволяє оцінити рівень сформованих знань, умінь і навичок та особистісних якостей майбутнього фахівця. Ми погоджуємося з думкою розробників, що магістерська робота дає можливість фахово оцінити майбутнього випускника, але за умови якісного виконання роботи. На наш погляд, якісне виконання магістерської роботи визначається наявністю асистентської практики для вирішення поставлених задач.

Висновок. Якісне вдосконалення процесу професійної підготовки магістра технологічної освіти стає можливим лише при переході на принципово інші методологічні та концептуальні основи іiі організації. Пропоновані концептуальні засади професійної підготовки магістрів розроблені при використанні аксіологічного, антропологічного, культурологічного, особистісно розвиваючого, компетентнісного, діяльнісного та системно-цілісного підходів до підготовки фахівців, а їі основою $є$ інтеграція теоретичної та практичної підготовки майбутніх викладачів, орієнтована на реалізацію загального, особливого та індивідуального.

\section{ЛІТЕРАТУРА}

1. Гончаренко С. У. Дидактична концепція змісту освіти / С. У. Гончаренко // Сучасні інформаційні технології та інноваційні методики навчання в підготовці фахівців: методологія, теорія, досвід, проблеми: зб. наук. пр. - К.; Вінниця, 2002. - Вип. 2. C. $22-26$.

2. Джеджула О. М. Теорія і методика графічної підготовки студентів інженерних спеціальностей вищих навчальних закладів: дис. доктора пед. наук: 13.00.04 / Джеджула Олена Михайлівна. - К., 2007. $460 \mathrm{c}$.

3. Коберник О.М. Теоретико-методологічні засади технологічної та професійної освіти / О.М. Коберник. - Наукові записки. Серія: Педагогіка. - 2011. - № 3. - C. $15-22$.

4. Ткачук С.I. Особливості підготовки та професійної діяльності вчителів технологій в умовах інформатизації освіти / С. І. Ткачук // Педагогіка вищої та середньої школи. - 2014. - Вип. 42. - С. 80-86. - Режим доступу: http://nbuv.gov.ua/UJRN/PVSSh_2014_42_18

5. Ящук С. М. Особливості моделювання процесу професійної підготовки магістрів технологічної освіти у вищих педагогічних навчальних закладах / C. М. Ящук // Педагогічні науки: теорія, історія, інноваційні технології: наук. журн. / гол. ред. А. А. Сбруєва. - Суми: Вид-во СумДПУ імені А. С. Макаренка, 2015. - № 5 (49). - С. 432-440.

\section{REFERENCES}

1. Honcharenko, S. U. (2002). Dydaktychna kontseptsiia zmistu osvity [Didactic concept of educational content]. The modern information technologies and innovative methods of training in the process of preparing the specialists: the methodology, theory, experience, and problems: A collection of scientific works. Kyiv; Vinnytsia, no.2, pp. 22-26. [in Ukrainian].

2. Dzhedzhula, O. M. (2007). Teoriia i metodyka hrafichnoi pidhotovky studentiv inzhenernykh spetsialnostei vyshchykh navchalnykh zakladiv [Theory and methods of graphic preparation of students of engineering specialties of higher educational institutions]. Doctor's thesis. Kyiv, p. 460. [in Ukrainian].

3. Kobernyk, O.M. (2011). Teoretyko-metodolohichni zasady tekhnolohichnoi ta profesiinoi osvity [Theoretical and methodological principles of technological and professional education]. Proceedings. Series: Pedagogy, no.3, pp. 15-22. [in Ukrainian].

4. Tkachuk, S.I. (2014). Osoblyvosti pidhotovky ta profesiinoi diialnosti vchyteliv tekhnolohii v umovakh informatyzatsii osvity [Features of training and professional activity of technology teachers in the conditions of informatization of education]. Pedagogy of higher and secondary schools, no.42, pp. 80-86. [in Ukrainian].

5. Iashchuk, S. M. (2015). Osoblyvosti modeliuvannia protsesu profesiinoi pidhotovky mahistriv tekhnolohichnoi osvity u vyshchykh pedahohichnykh navchalnykh zakladakh [Features of simulation of the process of professional training of masters of technological education in higher pedagogical educational institutions]. Pedagogical sciences: theory, history, innovative technologies. Sumy: Vyd-vo SumDPU imeni A. S. Makarenka, no. 5 (49). pp. 432-440. [in Ukrainian].

Стаття надійшла до редакції 05.03.2018

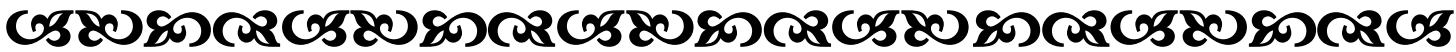

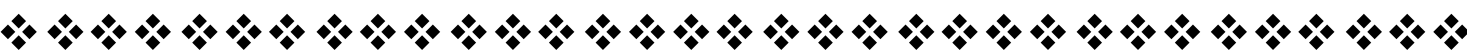

